\title{
Gender Dimension in the Development of Effective Teaching Skills among University of Cape Coast (Ucc) Distance Education Students
}

\author{
Paul Dela Ahiatrogah ${ }^{1, *}$ \\ ${ }^{1}$ College of Distance Education, University of Cape Coast, Cape Coast, Ghana \\ *Correspondence: College of Distance Education, University of Cape Coast, Cape Coast, Ghana. E-mail: \\ pauldela57@yahoo.com
}

Received: January 24, 2017

Accepted: July 7, 2017 Online Published: August 6, 2017

doi:10.5430/wje.v7n4p12

URL: https://doi.org/10.5430/wje.v7n4p12

\begin{abstract}
The study examined gender dimension in the development of effective teaching skills among distance education (DE) students. The conceptual framework for the study is gender mainstreaming which centres on pluralistic approach to diversity issues among both men and women. A longitudinal developmental research design was used for the study. A sample size of 376 distance education students made up of 173(46.01\%) female and $203(53.99 \%)$ male were purposefully selected from 5 regional study centres of College of Distance Education, University of Cape Coast (UCC) across Ghana. Data was collected using the Teaching Practice (Practicum) Assessment Form 'A' of UCC. The two research questions sought to find out the performance of male and female DE students on On-Centre Teaching Practice (OCTP) and School-Based Teaching Practice (SBTP) respectively. Five hypotheses were also formulated to guide the study. Results of the study revealed that the teaching skills acquired by both male and female DE students during OCTP and SBTP were good. However, a statistically significant difference exists between the teaching skills acquired by male and female DE students. Similarly, gender was found to have effect on the acquisition of teaching skills. It is recommended that all policy makers in the area of teaching practice should be mindful of gender issues in the development of teaching skills. Institutions involved in training teachers using distance education mode should stress the four levels of effective teaching skills assessed in this paper for meaningful practical teaching during teaching practice.
\end{abstract}

Keywords: gender; teaching skills; distance education; teaching practice; teacher trainees

\section{Introduction}

Teacher training, like most professional training programmes, operates in stages at either pre-service or in-service levels. Initial teacher training forms the entry level qualification for a teacher according to the official standards of most developing countries including Ghana. It may be taken as a pre-service programme or an in-service one. There are thirty eight public colleges of education that turn out about 9,000 teacher's annually in Ghana yet we still do not have enough teachers to man all the basic schools. It has been observed that the expected and desired growth in the teaching force is far beyond the capacity of the conventional public colleges of education. The supply of teachers is also adversely affected by low retention rates for newly trained teachers due to low remuneration and lack of job satisfaction. Significant numbers of teachers are also being lost to other sectors of the economy which are more attractive in terms of high pay, job satisfaction, and security.

Various attempts have been made to address the problem of teacher shortage in Ghana. These attempts led to the realization that the conventional mode of training teachers in boarding institutions is no longer adequate in meeting the demand of teachers required in Ghana, given the increasing number of basic schools that are without teachers. The initial training of teachers is also not able to bring teachers' professional skills to the level required. Various studies have shown that using distance education (DE) to train teachers might be the way forward (Aboagye and Ahiatrogah, 2010; Ahiatrogah, 2010). Being an effective mode of teacher training distance education (DE) is able to meet the increasing demand for eligible and certified teachers and the implementation of nation-wide curriculum initiatives.

The advantages of distance education (DE) in the training of teachers are quite huge. First, acquiring the qualification 
will enable teachers meet the criteria for take-home-pay and thus positively affect their motivation to give off their best. Second, DE ensures that classrooms are not deserted by teachers for further studies. Third, DE can produce teachers who are equally competent and qualified compared to their traditionally trained counterparts. Finally, it has the potential to increase access to training for marginalised and disadvantaged groups, such as women and people living in rural areas because DE does not require long periods of time away from family and domestic commitments (UNESCO, 2001).

Every DE program for training teachers is aimed at improving teachers' knowledge and skills. Knowledge in this context refers to their content knowledge, that is, deep knowledge of the subject they teach (Shulman, 1986) and their knowledge about learning styles or assessment or instruction ( $\mathrm{Ng} \& \mathrm{Tan}, 2017)$. This classification is usually termed as "propositional knowledge." The domain knowledge, encompasses skills which also consist of processes, procedures, and strategies that help teachers perform certain tasks. Examples of a skill may include problem solving, knowing how to teach hard content in a way that is understandable to learners. Another example of a skill is organizing learners in heterogeneous collaborative teams. Knowing how to facilitate a meaningful discussion among students is a skill. Skills may be considered "procedural knowledge" (UNESCO, 2001).

Possessing both propositional and procedural knowledge is essential for any effective teacher. Nevertheless, guidance and modeling is required when learning the skills of effective teaching. As part of a continuous improvement cycle, abundant opportunities for practice, structured feedback and reflection exists. King and Palmer (2006), explained 'skills development' as the productive capacities acquired through education and training in formal, non-formal and on-the-job settings. Skills development initiative enables individuals at all economic levels to engage productively in livelihoods and to adapt their capacities to meet the changing demands and opportunities of the economy and labour market. Women tend to have more obstacles in accessing training and skills development due to their multiple roles and responsibilities and gender bias in and outside the home. Skills can be acquired in a number of ways. Those working in the formal sector may receive training through employers. Workers in the informal sector learn skills on the job and through family members while working in family occupations. Skill transfer also takes place, although in smaller numbers, through vocational courses run by government agencies.

The University of Cape Coast through her College of Distance Education (CoDE) has mounted distance education programmes for the training of teachers and other professionals. This is enabling teachers to extend their existing knowledge and skills and develop new ones. The teacher training programme takes the form of long-structured courses leading to formal qualifications such as diplomas or bachelor's. The programme is designed in such a way that qualified and unqualified teachers alike participate in continuing professional development which is provided as in-service activities or on-the-job learning.

To become a professional teacher, one needs to display competence in teaching. Competence in teaching can only come after the acquisition of some set of skills. The said skills do not come automatically. They are acquired after careful training and exposure in the art of teaching. Teaching practice in most teacher training courses demands that trainees engage in practice teaching, spend several weeks in schools practicing to teach pupils. They are guided by tutors in the training institutions and by co-operating teachers (Cheng, 2017). The guidance mostly consists of discussion prior to teaching, occasional observation by a tutor or co-operating teacher of the trainee and a post-teaching discussion when the tutor or co-operating teacher comments on the student's performance (Oduro, 1998). For a basic teacher-training course in most countries including Ghana, the curriculum requires the teacher trainee to have at least twelve weeks of teaching practice. The twelve weeks may be divided into three sessions lasting for four weeks each. Some colleges prefer to have two sessions lasting six weeks each. Commenting on the importance of teaching practice, Macharia and Wario (1994) wrote that "teaching practice is an essential component of any teacher training course. It is perhaps, the most important component ... it is the responsibility of every college to organise effective teaching practice programmes for its trainees" (p. 1).

Teaching skills cover a range of areas which have engaged the attention of many researchers and writers for some time now. Duke and Gay (1989) said effective teaching is composed of at least four attributes: knowledge of what is being taught, enthusiasm for teaching, rapport between teacher and student, and organisation of the learning situation. According to Eggen, Kamp and Kauchak (2009) the essential teaching skills required to create productive learning environments include attitudes, organisation, communication, focus, feedback, questioning, review and closure. Bulber, Mohr and Walls (2002) identified outcomes, clarity, enthusiasm, and engagement as the four aces of effective teaching. In her review of international literature on teacher effectiveness, Hunt (2009) settled for knowledge, attitudes, and performance as the major skills needed by teachers. On his part De Rossi (2009) identified the adopter, the communicator, the learner, the visionary, the leader, the model, the collaborator, and the risk taker as 
eight habits of highly effective $21^{\text {st }}$ century teachers. Others outlined setting the scene, being student centred, assessing prior knowledge, asking questions, checking understanding, using visual aids, setting homework, and summarising and closing a session as the basic teaching skills required for effective teaching.

Rubio (2009) categorised effective teaching qualities into professional and personal skills. On professional skills, he argued strongly that to be an effective teacher does not only involve having a deep content knowledge, but also organisational, management and communication skills, being able to organise instructions, and providing relevant assessment and fair evaluations. In terms of personal skills, an effective teacher is responsible to create a warm classroom climate, to promote enthusiasm, motivation and an interactive teacher-student relationship. It also implies to be caring, and understandable, and above all, to enhance learning.

An important component of skills development is a labour market analysis, which identifies the supply of labour available for jobs. Gender issues need to be integrated into this analysis. Public and private partners must be committed to supporting the training and must be made aware that promoting female education and training reduces poverty and inequalities (Kumari, 2016).

The aim of this study is to compare the teaching skills of male and female teacher trainees on the distance education programmes. The study specifically zeroed in on the way in which DE teacher trainees teaching skills are reflected in the way they bring their lessons into focus, how they are able to teach in guided practice, how they are able to teach in order to promote collaborative learning, and finally how they are able to help the learner in independent practice skills. By examining if the gaps become statistically significant different between diploma and bachelor levels, we can better understand the effect of gender on teaching skills within the contexts in which the effect appears. The study would also try to establish whether gender has a bearing on the level of teaching skills DE teacher trainees acquire during teaching practice.

One of the crucial courses mounted to enhance the professional competence of DE teacher trainees, is teaching practice (practicum). It is taken in two different semesters at the diploma and degree levels. In all, students do On-Centre Teaching Practice (OCTP) two times and two times School-Based Teaching Practice (SBTP) under the guidance of their course tutors and mentors respectively. The emphasis is on the development of teaching skills. Even though equal attention is given to both male and female in this exercise, it has not been established whether there is equity in their development of teaching skills. It is also not known whether gender based differences exist in the development of teaching skills. Furthermore, we are not sure whether gender of DE teacher trainees affects their acquisition of teaching skills during teaching practice. Based on the issues identified, two research questions were raised for the study: 1. What is the performance of male and female DE students on OCTP? 2. What is the performance of male and female DE students on SBTP? The study was also guided by five hypotheses which were tested at 0.05 level of significance:

1. There is no statistically significant difference between the teaching skills acquired by male and female DE students during On-Centre-Teaching-Practice (OCTP).

2. Gender has no effect on DE students' teaching skills acquisition during OCTP.

3. There is no statistically significant difference between the teaching skills acquired by male and female DE students during School-Based-Teaching-Practice (SBTP).

4. Gender has no effect on DE students' teaching skills acquisition during SBTP.

5. There is no statistically significant improvement in the teaching skills acquired by male and female DE students after going through OCTP and SBTP.

\section{Conceptual Framework and Literature Review}

This study was conducted within the broad conceptual framework of gender mainstreaming. Gender mainstreaming according to Booth and Bennett, (2002) is the public policy concept of assessing the different implications for women and men of any planned policy action, including legislation and programmes, in all areas and levels. My view in this study is that teaching practice, which eventually leads to the acquisition of effective teaching skills, is no exception. Generally, gender mainstreaming is a questioned concept and practice. It is the re-invention, restructuring, and re-branding of a key part of feminism in the contemporary era. As a concept, it encapsulates many of the tensions and dilemmas in feminist theory and practice over the last decade and provides a new focus for debates on how to move them on (Beveridge, Nott \& Stephen, 2000; Behning \& Pascual, 2001; Mazey, 2000; Verloo, 2001; Walby, 2001; Woodward 2003). 
According to Walby (2004), gender mainstreaming involves at least two different frames of reference: one emanating from a 'gender equality' stance, and the other, the 'mainstream'. Thus at its core, gender mainstreaming is inevitably and essentially a contested process. One feature that is often included within definitions of gender mainstreaming is the practice of making visible the way that gender relations are significant in institutional practices where they had previously been seen as marginal or irrelevant, in order to facilitate the implementation of a strategy for both gender equality and for the improvement of the mainline policy.

Gender mainstreaming requires an equal representation of women and men in decision-making institutions (Lombardo, 2005). Every effort, therefore, needs to be made to broaden women's participation at all levels of decision-making (Charlesworth, 2005). One vision of gender mainstreaming is that it offers 'transformation' that is, neither the assimilation of women into men's ways, nor the maintenance of a dualism between women and men, but rather something new, a positive form of melding, in which the outsiders, feminists, changed the mainstream.

Kardia and Wright (2004) observed that teaching requires skills, insight, intelligence, and diligence. Faculty, therefore, struggles to succeed in a variety of ways in order to meet the challenges they face in the classroom. Both men and women teachers exhibit these traits in their lesson delivery; however, research evidence (Laird, Garver \& Niskode, 2007) suggested that they may meet the challenges in different ways. It is, therefore, important to understand how and why men and women teach differently because it is crucial in helping teachers in their efforts to improve upon their teaching skills.

Lacey, Saleh and Gorman (1998) found in a study that the teaching styles of male and female teachers differed, especially in terms of how much each of the genders valued student inclusion in lesson delivery. On his part, the findings of Grasha (1994)'s study suggested that women were more likely to use a facilitator or delegator style that emphasizes relating to students as a guide, consultant, or resource as opposed to transmitting knowledge, setting goals, and providing feedback. A similar study by Singer (1996) indicated that gender was a significant predictor of teachers' attitudes and behaviour in teaching.

Statham, Richardson and Cook (1991) found that women professors spent significantly greater proportion of time encouraging and allowing student participation in their teaching than men professors. Similarly, they established that men spent less instructional time soliciting responses from their students where as women used more time in doing the same activity. In another study, Laird, Garver and Niskode (2007) found gender differences in the percentage of class time spent on various activities, measure of teaching style, but the gaps between men and women in lecturing and active classroom practices can vary by factors including disciplinary area and course size.

In another study, the National Survey of Student Engagement (2005) revealed that women faculty members emphasize higher order thinking skills, active and collaborative learning, and diversity experiences more than men. To crown it all, Kuh, Nelson Laird and Umbach (2004) found that women are more likely than their male counter parts to value and use effective educational practices such as placing an emphasis on academic challenge and enriching educational experiences.

Starbuck (2003) examined gender differences in teaching styles and found that only small group discussion, lecture, and the use of power-point slides were the three activities significantly different after controlling for discipline. This might be an indication that gender differences are not consistent across disciplinary areas, and perhaps, other context indicators. It is, therefore, important to establish how men and women teachers teach differently and also examine whether gender differences in teaching may change.

\section{Methodology}

A longitudinal developmental research design was used for this study since it involves collection of data from the same individuals (or groups) across time. Basically, the teaching practice (practicum) scores of DE students on the diploma programme were followed through to the post diploma levels to compare the levels of skills acquisition. Observing change in these individuals gives a better basis for causal inference than a cross-sectional study. The major problem with prospective longitudinal studies is attrition brought about by such factors as mobility, death, changing name through marriage, or refusal (Calderwood \& Lessof, 2009). However, one advantage of the longitudinal study is that it avoids cohort effects because the researcher examines one group of people over time, rather than comparing several different groups that represent different ages and generations. Another advantage is that in principle the distributions of key variables in the original sample can be restored by differential weighting of the sample in later sweeps. The related problem is missing data, occurring at question level, which can seriously reduce the size of the data set for analysis across different sweeps. Statistical methods of imputation are often used to 
estimate missing values in these instances, but none is able fully to address the possible biases brought about by this form of sample loss (Calderwood \& Lessof, 2009). The disadvantages notwithstanding, I still think it is the best design since care had been taken to minimize the effect of the disadvantages.

The target population of the study was 7,521 Diploma in Basic Education students in all the ten regions in Ghana in the 2009/10 academic year. The accessible population however was all final year students in five regions. A sample size of 376 students made up of 203 male and 173 female was purposively selected from the accessible population. All the subjects for this study had gone through the diploma and bachelor programmes successfully.

The teaching practice (practicum) Assessment Form "A" of the University of Cape Coast was used in assessing the teaching skills of the distance teacher trainees. The assessment form has been classified into four (4) areas for the purposes of this study. The first section dealt with skills needed in bringing a lesson into focus (5 items) while section two covered skills used in teaching guided practice (6 items). The third section centred on collaborative learning skills (6 items) whiles the last section reflected independent practice skills ( 3 items). The assessment form was structured on a five point Likert scale involving weak, below minimum, minimum, good, and outstanding.

The researcher obtained the practicum assessment records of the selected DE teacher trainees from the Assessment Unit and followed up to the Teaching Practice Unit of CoDE to select the Form A of the sample. The practicum assessment scores for On-Centre Teaching Practice (OCTP) and School-Based Teaching Practice (SBTP) were obtained for each selected student. The scores on the Form A were regrouped to reflect the variables of interest in this study.

The assessment data was edited, coded and scored using Likert's rating scale of: outstanding (5), good (4), minimum (3), below minimum (2), and weak (1). Percentage, mean, standard deviation, t-test and regression were the statistical tools used to analyse the data. The mean value for the four thematic skill areas range between 3.71 and 3.87. The standard deviations were between .344 and .457 .

\section{Results of the Study}

The objective of Research Question 1 focuses on the gender base assessment of DE Students OCTP performace. The data on this section was analyzed in Table 1.

\section{Research Question 1}

What is the performance of male and female DE students on OCTP?

The data collected in respect of OCTP is presented in Table 1.

Table 1. Gender Base Assessment of DE Students OCTP

\begin{tabular}{lcccccc}
\hline Aspect of Lesson Delivery & \multicolumn{3}{c}{ Male (203) } & \multicolumn{3}{c}{ Female (173) } \\
\cline { 2 - 6 } & Minimum & Good & $\begin{array}{c}\text { Out } \\
\text { standing }\end{array}$ & Minimum & Good & $\begin{array}{c}\text { Out } \\
\text { standing }\end{array}$ \\
\hline Bringing a Lesson into Focus & $56(27.6 \%)$ & $146(71.9 \%)$ & $1(0.5 \%)$ & $23(13.3 \%)$ & $149(86.1 \%)$ & $1(0.6 \%)$ \\
Guided Practice skills & $45(22.2 \%)$ & $158(77.8 \%)$ & - & $20(11.6 \%)$ & $153(88.4 \%)$ & - \\
Collaborative learning skills & $56(27.6 \%)$ & $146(71.9 \%)$ & $1(0.5 \%)$ & $25(14.5 \%)$ & $148(85.0 \%)$ & - \\
Independent practice skills & $59(29.1 \%)$ & $144(70.9 \%)$ & - & $25(14.5 \%)$ & $147(85.0 \%)$ & $1(0.6 \%)$ \\
Overall assessment of OCTP & $35(17.2 \%)$ & $168(82.8 \%)$ & - & $14(8.1 \%)$ & $159(91.9 \%)$ & - \\
\hline
\end{tabular}

TP Data, 2010 - 2012

From Table 1, the analysis revealed that more females (percentage wise) were rated as good performers in the area of guided practice and they were also assessed as good in the ability to bring a lesson into focus. Similarly, 146 (71.9\%) male against $148(85.0 \%)$ female were declared good in the promotion of collaborative learning in teaching. The overall assessment of OCTP presented in Table 1 reveals that more females were assessed as good in OCTP as compared to males in terms of percentages.

The objective of Research Question 2 focuses on the gender base assessment of DE Students SBTP performace. The data on this section was analyzed in Table 2.

Research Question 2

What is the performance of male and female DE students on SBTP? 
The second aspect of the data gathered dealt with SBTP. The analysis of the said data is tabulated in Table 2

Table 2. Gender Base Assessment of DE Students SBTP

\begin{tabular}{lcccccc}
\hline Aspect of Lesson Delivery & \multicolumn{3}{c}{ Male (203) } & \multicolumn{2}{c}{ Female (173) } \\
\cline { 2 - 6 } & Minimum & Good & $\begin{array}{c}\text { Out } \\
\text { standing }\end{array}$ & Minimum & Good & $\begin{array}{c}\text { Out } \\
\text { standing }\end{array}$ \\
\hline Bringing a Lesson to Focus & $7(3.5 \%)$ & $182(89.7 \%)$ & $14(6.9 \%)$ & $6(3.5 \%)$ & $155(89.6 \%)$ & $12(6.9 \%)$ \\
Guided Practice skills & $2(1.0 \%)$ & $199(98.0 \%)$ & $2(1.0 \%)$ & - & $168(97.1 \%)$ & $5(2.9 \%)$ \\
Collaborative learning skills & $8(3.9 \%)$ & $144(70.9 \%)$ & $51(25.1 \%)$ & $4(2.3 \%)$ & $128(74.0 \%)$ & $41(23.7 \%)$ \\
Independent practice skills & $2(13.3 \%)$ & $152(74.9 \%)$ & $24(11.8 \%)$ & $19(11.0 \%)$ & $145(83.8 \%)$ & $9(5.2 \%)$ \\
Overall assessment of OCTP & $4(2.0 \%)$ & $180(88.7 \%)$ & $19(9.4 \%)$ & $1(0.6)$ & $149(86.1 \%)$ & $23(13.3 \%)$ \\
\hline
\end{tabular}

TP Data, 2010 - 2012

The data tabulated in Table 2 revealed that $199(98.0 \%)$ and $168(97.1 \%)$ male and female DE students respectively were assessed as good in guided practice skills in teaching. Again, about the same percentage of male and female DE students were also rated as good in being able to bring a lesson into focus. However, in terms of percentages, more female DE students were rated as good performers in the area of independent practice. Similarly, a lot of the female DE students than their male counterparts judged their performance in a collaborative learning skills as good. On the whole, $180(88.7 \%)$ and $149(86.1 \%)$ male and female respectively were assessed as good performers in SBTP while less male than female DE students were judged to be outstanding as far as SBTP is concerned.

\section{Testing of Hypotheses}

Hypothesis 1 sought to find the differences between the teaching skills acquired by male and female DE students during On-Centre-Teaching-Practice (OCTP).

Hypothesis 1

There is no statistically significant difference between the teaching skills acquired by male and female DE students during On-Centre-Teaching-Practice (OCTP).

Table 3. Gender Difference in Assessment of OCTP

\begin{tabular}{lllllll}
\hline \multirow{2}{*}{ Aspect of Lesson Delivery } & \multicolumn{3}{c}{ Male (203) } & \multicolumn{2}{c}{ Female (173) } & \\
\cline { 2 - 5 } & Mean & SD & Mean & SD & tvalue & $\mathrm{p}$ \\
\hline Bringing a Lesson to Focus & 3.73 & .457 & 3.86 & .373 & 38.54 & $.000^{*}$ \\
Guided Practice skills & 3.77 & .431 & 3.87 & .344 & 26.84 & $.000^{*}$ \\
Collaborative learning skills & 3.73 & .456 & 3.85 & .374 & 33.57 & $.000^{*}$ \\
Independent practice skills & 3.71 & .455 & 3.85 & .384 & 38.95 & $.000^{*}$ \\
Overall assessment of OCTP & 3.83 & .379 & 3.91 & .302 & 23.36 & $.000^{*}$ \\
\hline
\end{tabular}

TP Data, $2010-2012 \quad{ }^{*} \mathrm{p}<0.05$ (significant)

The analysis shown in Table 3 indicates that all the indicators of effective teaching assessed recorded difference between male and female DE students. Specifically, female performance was rated higher in ability to bring a lesson into focus $(3.86>3.73)$, guided practice skills $(3.87>3.77)$, collaborative learning skills $(3.85>3.73)$, and independent practice skills $(3.85>3.71)$. On the whole, a statistically significant difference between male and female DE students performance in OCTP, $\mathrm{t}(374)=23.36, \mathrm{p}=.000(\mathrm{p}<0.05)$ with a mean score $(3.91>3.83)$ in favour of female. The null hypothesis that there is no statistically significant difference between the teaching skills acquired by male and female DE students during On-Centre-Teaching-Practice (OCTP) is rejected.

The main purpose of formulating Hypothesis 2 was to test the effect of gender on DE students' teaching skills acquisition during OCTP. One of the issues addressed in this paper is to know the extent to which gender predicts the teaching skills of DE students on teaching practice during OCTP.

Hypothesis 2

Gender has no effect on DE students' teaching skills acquisition during OCTP.

The result of the data analysis in this regard is presented in Table 4. 
Table 4. Regression Analysis of Effect of Gender on Teaching Skills Acquisition during OCTP

\begin{tabular}{llrrrrr}
\multicolumn{7}{c}{ ANOVA $^{\mathbf{b}}$} \\
\hline Regression & Analysis of & \multicolumn{3}{c}{ Mean } \\
Analysis & variance & Sum of Squares & df & \multicolumn{1}{c}{ Square } & F & Sig. \\
\hline $\mathrm{R}=.194^{\mathrm{a}}$ & Regression & 3.514 & 5 & .703 & 2.893 & $.014^{\mathrm{a}}$ \\
$\mathrm{R}^{2}=.038$ & Residual & 89.888 & 370 & .243 & & \\
$\mathrm{SE}=.49289$ & Total & 93.402 & 375 & & & \\
\hline
\end{tabular}

b. Dependent Variable: Gender of student

The analysis in Table 4 indicates that the independent variable yielded a coefficient of multiple regression (R) of 0.123 and an adjusted $\mathrm{R}^{2}=0.012$. This implies that $1.2 \%$ of the total variance in the acquisition of teaching skills during OCTP is accounted for by gender. The data in Table 4 further shows that the analysis of variance of the multiple regression data produced F-ratio value of $\mathrm{F}(1,374)=5.745, \quad \mathrm{p}<0.05$ which indicated the effectiveness of gender in predicting teaching skills. The null hypothesis that gender has no effect on DE students' teaching skills acquisition during OCTP is rejected.

Table 5. Relative Contribution of Gender to Acquisition of Teaching Skills during OCTP

\section{Coefficients $^{\mathrm{a}}$}

\begin{tabular}{|c|c|c|c|c|c|}
\hline \multirow[t]{2}{*}{ Model } & \multicolumn{2}{|c|}{$\begin{array}{c}\text { Unstandardized } \\
\text { Coefficients }\end{array}$} & \multirow{2}{*}{$\begin{array}{c}\text { Standardized } \\
\text { Coefficients }\end{array}$} & \multirow[b]{2}{*}{$\mathrm{t}$} & \multirow[b]{2}{*}{ Sig. } \\
\hline & $\mathrm{B}$ & Std. Error & & & \\
\hline (Constant) & .613 & .291 & & 2.107 & .036 \\
\hline Skills of bringing a lesson to focus & .132 & .094 & .112 & 1.404 & .161 \\
\hline Guided practice skills & .058 & .103 & .046 & .567 & .571 \\
\hline Collaborative learning skills & .016 & .097 & .014 & .167 & .868 \\
\hline Independent practice skills & .159 & .086 & .137 & 1.849 & .065 \\
\hline Overall teaching skills of DE students & -.139 & .139 & -.097 & -1.005 & .316 \\
\hline
\end{tabular}

a. Dependent Variable: Gender of student $\quad *_{p}<0.05$ (significant)

The analysis in Table 5 shows the predictor variables as they regressed against the dependent variables. The results show that the beta values for all the variables were found not to enter the regression equation and their beta values were also found not to be significant.

The extent to (a) which a difference between the teaching skills acquired by male and female DE students during School-Based-Teaching-Practice (SBTP) is tested under Hypothesis 3.

Hypothesis 3

There is no statistically significant difference between the teaching skills acquired by male and female DE students during School-Based-Teaching-Practice (SBTP).

Result of the data analysis on the teaching skills acquired by the male and female DE students during SBTP is presented in Table 6.

Table 6. Gender Difference in Assessment of SBTP

\begin{tabular}{lllllll}
\hline \multirow{2}{*}{ Aspect of Lesson Delivery } & \multicolumn{3}{c}{ Male (203) } & \multicolumn{2}{c}{ Female (173) } & \\
\cline { 2 - 5 } & Mean & SD & Mean & SD & tvalue & p \\
\hline Bringing a Lesson to Focus & 4.01 & .403 & 4.03 & .322 & .003 & .956 \\
Guided Practice skills & 4.00 & .141 & 4.02 & .168 & 5.631 & $.018^{*}$ \\
Collaborative learning skills & 4.21 & .497 & 4.22 & .464 & .615 & .433 \\
Independent practice skills & 3.98 & .502 & 3.94 & .399 & 1.861 & .173 \\
Overall assessment of SBTP & 4.07 & .329 & 4.13 & .351 & 4.353 & $.038^{*}$ \\
\hline
\end{tabular}

TP Data, $2010-2012 * \mathrm{p}<0.05$ (significant) 
The result of the analysis tabulated in Table 6 portrays that there is a statistically significant difference between male and female DE students on SBTP only in terms of the use of guided practice skills, $t(374), 5.31, p=.018(p<0.05)$ with a mean difference of $(4.02>4.00)$ in favour of female. The analysis showed further differences in the rest of the indicators; but the differences were not statistically significant. On the whole however, a statistically significant difference between male and female DE students on SBTP, $\mathrm{t}(374), 4.53, \mathrm{p}=.038(\mathrm{p}<0.05)$ with a mean difference of $(4.13>4.07)$ in favour of female. The study, therefore, failed to accept the null hypothesis that there is no statistically significant difference between the teaching skills acquired by male and female DE students during School-Based-Teaching-Practice (SBTP).

The effect of gender of DE students' teaching skills acquisition during SBTP is analysed under hypothesis 4 .

Hypothesis 4

Gender has no effect on DE students' teaching skills acquisition during SBTP.

Table 7 displays the result of the data analysis on gender effect on DE students' teaching skills acquisition during SBTP.

Table 7. Regression Analysis of Effect of Gender on Teaching Skills Acquisition during SBTP

\begin{tabular}{|c|c|c|c|c|c|c|}
\hline $\begin{array}{l}\text { Regression } \\
\text { Analysis }\end{array}$ & $\begin{array}{l}\text { Analysis of } \\
\text { variance }\end{array}$ & Sum of Squares & $\mathrm{df}$ & $\begin{array}{l}\text { Mean } \\
\text { Square }\end{array}$ & $\mathrm{F}$ & Sig. \\
\hline $\mathrm{R}=.144^{\mathrm{a}}$ & Regression & 1.856 & 5 & .371 & 1.500 & $.189^{\circ}$ \\
\hline $\mathrm{R}^{2=} .007$ & Residual & 91.545 & 370 & .247 & & \\
\hline $\mathrm{SE}=.49741$ & Total & 93.402 & 375 & & & \\
\hline
\end{tabular}

Table 7 presents the value of the parameters of the regression analysis between the predictor variable and teaching skills. Taken jointly, the predictor variable against the criterion variable yielded a coefficient of multiple correlation (R) of .144; and adjusted multiple correlation square $\left(\mathrm{R}^{2}\right)$ of .007 . This is translated into .7\% of the observed variance of teaching skills. The analysis also recorded a standard error (SE) of .49741 and F-value of 1.500 significant at an alpha level of .05 .

Table 8. Relative Contribution of Gender to Acquisition of Teaching Skills during SBTP

\section{Coefficients $^{\mathrm{a}}$}

\begin{tabular}{lccccc}
\hline Model & \multicolumn{3}{c}{$\begin{array}{c}\text { Standardized } \\
\end{array}$} & \multicolumn{3}{c}{ Unstandardized Coefficients } & Coefficients & & \\
\cline { 2 - 4 } & $\mathrm{B}$ & Std. Error & Beta & $\mathrm{t}$ & Sig. \\
\hline (Constant) & .434 & .690 & & .629 & .530 \\
Bringing a lesson into focus & -.008 & .082 & -.006 & -.101 & .920 \\
Guided practice skills & .252 & .180 & .078 & 1.397 & .163 \\
Collaborative learning skills & -.065 & .064 & -.062 &.-1.005 & .316 \\
Independent practice skills & -.092 & .060 & -.085 & -1.528 & .127 \\
Overall teaching skills of DE students & .167 & .107 & .114 & 1.562 & .119 \\
\hline
\end{tabular}

a. Dependent Variable: Gender of student $\quad{ }^{*} \mathrm{p}<0.05$ (significant)

From the analysis presented in Table 8, none of the F-ratio is statistically significant. The beta values of bringing a lesson into focus $(B=-.008 ; p>0.05)$; collaborative learning skills; $(B=-.065 ; p>0.05)$; and independent practice skills; $(\mathrm{B}=-.092 ; \mathrm{p}>0.05)$ significantly had some gender influence. Indeed, the negative value of regression coefficient (B) indicates that the indicators had some inverse relationship with gender.

The objective of hypothesis 5 is to identify whether male and female DE students after going through OCTP and SBTP exhibit any improvement in their acquired teaching skills.

Hypothesis 5 
Table 9. Gender Difference in Assessment of OCTP

\begin{tabular}{|c|c|c|c|c|c|c|}
\hline \multirow{2}{*}{ Form of Teaching Practice } & \multicolumn{2}{|c|}{ Male (203) } & \multicolumn{2}{|c|}{ Female (173) } & \multirow[b]{2}{*}{ tvalue } & \multirow[b]{2}{*}{$\mathrm{p}$} \\
\hline & Mean & SD & Mean & SD & & \\
\hline On-Centre Teaching Practice & 3.82 & .379 & 3.91 & .302 & 23.361 & $.000^{*}$ \\
\hline School-Based Teaching Practice & 4.07 & .329 & 4.13 & .351 & 4.353 & $.000 *$ \\
\hline
\end{tabular}

TP Data, $2010-2012 * \mathrm{p}<0.05$ (significant)

The data analyzed in Table 9 reveals male DE students experience a mean difference $(4.07>3.82)$ in favour of SBTP. Similarly, the female counterparts also had a mean difference $(4.13>3.91)$ in favour of SBTP. This gives sufficient grounds for the null hypothesis that there is no statistically significant improvement in the teaching skills acquired by male and female DE students after going through OCTP and SBTP to be rejected.

In summary, the study revealed that both male and female DE students acquired good teaching skills during OCTP and SBTP. Statistically significant difference was found between the teaching skills of bringing lesson into focus, guided practice, collaborative learning, and independent practice acquired by male and female DE students in favour of female. It was also established that gender has effect on the teaching skills acquired by DE students during OCTP and SBTP.

\section{Discussion}

Basically, this study assessed the teaching skills acquired by DE teacher trainees. The study focused on the gender dimension to the advancement of effective teaching skills among DE students at the University of Cape Coast. The study revealed that both male and female DE students acquired good teaching skills during OCTP and SBTP. This finding collaborate Markauskaite's (2006) study which concluded that female and male trainee teachers have similar self-learning experiences. This is very delighting because of the negative notion being peddled around that training teachers through DE is not an effective way of ensuring teaching competence. It is, therefore, important to intimate that teaching practice plays a pivotal role in all teacher training programmes whether by convectional means or distance education because it ensures effective acquisition of teaching skills by both male and female.

It also came out clearly in this study that even though both male and female DE students acquired good teaching skills during OCTP and SBTP, statistically significant difference was found between the teaching skills acquired by male and female DE teacher trainees in favor of female. Interestingly, Hobson, et al (2006) observed in their research on student teachers' experiences of initial teacher training in England, that men training to teach in primary schools were more likely than women to give lower ratings of the assessment of their teaching, whilst this was not the case for secondary phase respondents. On the contrary, Braten and Stromso (2006) found significant gender differences in self-reported learning patterns of teacher trainees. Males indicated higher level of participation in Internet based communication activities than females. Females reported higher levels of strategy use when learning from conventional texts. On the other hand, Markauskaite (2006) noted that male students were significantly more confident about their capabilities for mastering new applications autonomously. It is clear from these research findings that the gender differences bother on the learning situation and context.

Effective teaching skills have been identified as the ability to bring a lesson to focus; guided practice; collaborative learning; and independent practice skills. The first stage in every effective teaching is the ability to bring a lesson into focus (Darling-Hammond, 2017). This provides students with the hope of what is to follow or an advanced organizer of what is to come in the lesson. The way in which a lesson is introduced sets the tone for effective teaching. It is, therefore, important to do so in fun and creative ways in order to generate interest and excitement among students and help to make the lesson more successful. This skill is very important because it sets the tone for every effective lesson delivery.

The emphasis in guided practice skills is on learning by practicing, observing, and thinking. While students are working, the teacher goes round to find out how well students understand the lesson taught. The teacher provides extra comments as appropriate for students to get better understanding. It has been revealed in this study that male and female DE students exhibit different levels of skills used in teaching during guided practice stage in favour of female. This finding confirms Grasha (1994)'s study which suggested that women relate to students as a guide more than their male counterparts. It also collaborates Stathan, Richardson and Cook's (1991) assertion that women professors spent significantly greater proportion of time encouraging and allowing student participation in their teaching than men. 
Another area of concern in this study was collaborative learning skills used in teaching. According to UNESCO (2001), organizing learners in heterogeneous collaborative teams and knowing how to facilitate a meaningful discussion among students is a powerful skill for every competent teacher. Collaborative learning activities include group projects, joint problem solving, debates, study teams, and other activities. It also occurs when pupils and teachers engage in play, work and other activities together. It has been established in this study that statistically significant difference exists between male and female DE students in their use of collaborative learning skills in teaching. It also confirms an earlier study conducted by the National Survey of Students Engagement (2005) which indicated that women faculty members emphasize collaborative learning more than men.

To be successful in school and prepared for life after school, students need to be independent learners. This is what happens at the independent practice stage of teaching. Independent practice can take the form of homework, assignment, class seat work or worksheet. At this stage, students have the chance to reinforce skills and synthesize their new knowledge by completing a task on their own and away from the teacher's guidance. It also ensures that students identify the relevant skills to everyday life and make them desire to acquire these skills for themselves. The findings of this study revealed gender base differences in teaching skills centred on independent practice. This finding compliments Statham, Richardson and Cook (1991) assertion that men spent less instructional time soliciting responses from their students where as women used more time in doing the same activity. The observed gender gaps cited in this study if not addressed properly during pre-service training, could later be transferred into the classroom and this can negatively affect children's learning.

\section{Conclusion and Recommendation}

This study examined the gender dimension in acquiring effective teaching skills among DE teacher trainees. The study revealed that gender accounts for differences in the acquisition of teaching skills by DE teacher trainees. Although it is difficult to detect precisely what causes gender differences, one cannot rule out completely time spent on various aspects of effective teaching practice. It is, therefore, recommended that all policy makers in the area of teaching practice should be mindful of gender issues in the development of teaching skills. Institutions involved in training teachers using distance education mode should stress the ability to bring a lesson to focus; guided practice; collaborative learning; and independent practice skills for meaningful practical teaching experience. Policy makers and Distance Education institutions should be looking at the development comprehensive frameworks to factor gender differences into OCTP and SBTP. It is further recommended that male DE teacher trainees change their attitude towards OCTP and SBTP and rather focus on the enhancement of professional understanding and experience in teaching. Ministries of Education should also create an environment to help equip DE institutions with resources for more capacity building in the area of training in teaching practice. In the future, it is also suggested that a similar study focusing on OCTP and SBTP across universities will be very useful whiles expanding on this current study.

\section{References}

Aboagye, J. K., \& Ahiatrogah, P. D. (2010). Comparison of Distance Education Modes of Training Teachers in Universities in Ghana. International Journal of Educational Leadership (IJEL), 2(2), 55-78.

Ahiatrogah, P. D. (2010). Differential levels of Challenges in training teachers through distance education in Ghana. International Journal of Multicultural Education, 4(1), 1-16.

Behning, U., \& Pascual, A. S. (2001). Comparison of the adaptation of gender mainstreaming in national employment strategies. In Ute Behning and Amparo Serrano Pascual (Eds.), Gender Mainstreaming in the European Employment Strategy. (Brussels: European Trade Union Institute). pp. 321-345.

Beveridge, F., Nott, S., \& Stephen, K. (2000). Mainstreaming and the engendering of policy-making: A means to an end? Journal of European Public Policy, 7(3), 385-405. https://doi.org/10.1080/13501760050086099

Booth, C., \& Bennett, A.(2002. Gender Mainstreaming in the European Union. European Journal of Women's Studies, 9(4), 430-446. https://doi.org/10.1177/13505068020090040401

Braten, I., \& Stromso, H. I. (2006). Epistemological beliefs, interest, and gender as predictors of Internet-based learning activities. Computers in Human Behaviour. https://doi.org/10.1016/j.chb.2004.03.026

Bulger, S.M., Mohr, D.J., \& Walls, R.T. (2002). Stack the deck in favor of your students by using the four aces of effective teaching. Effective Teaching, 5(2).

Calderwood, L., \& Lessof, C. (2009). 'Enhancing Longitudinal Surveys by Linking to Administrative Data. In Lynn, 
P. (Ed.), Methodology of Longitudinal Surveys, Chichester, UK: Wiley. https://doi.org/10.1002/9780470743874.ch4

Charlesworth, H. (2005). 'Not waving but Drowning: Gender Mainstreaming and Human Rights in the United Nations', 18 HARV. HUM. RTS. J. 1.

Cheng, J. (2017). Learning to attend to precision: the impact of micro-teaching guided by expert secondary mathematics teachers on pre-service teachers' teaching practice. ZDM, 49(2), 279-289. https://doi.org/10.1007/s11858-017-0839-7

Darling-Hammond, L. (2017). Teacher education around the world: What can we learn from international practice?. European Journal of Teacher Education, 1-19. https://doi.org/10.1080/02619768.2017.1315399

De Rossi, L. C. (2009). Teaching Skills: What 21 st Century Educators Need To Learn To Survive. Retrieved June 23 2012

from

http://www.masternewmedia.org/teaching-skills-what-21st-century-educators-need-to-learn-to-survive/\#ixzz2g PmiOqiY

Dukes, R. L., \& Gay, V. (1989). The Effects of Gender, Status, and Effective teaching on the Evaluation of College Instruction. Teaching Sociology, 17, 447-457. https://doi.org/10.2307/1318422

Eggen, P., Kamp, D., \& Kauchak, D. (2009). Educational Psychology - Windows on classrooms ( $8^{\text {th }}$ ed.). Pearson International edition, New Jersey: Pearson Education.

Grasha, A.F. (1994). A matter of style: The teacher as expert, formal authority, Personal model, facilitator, and delegator. College Teaching, 42(4), 142-149.

Hobson, A.J., Malderez, A., Tracey, L., Giannakaki, M.S., Kerr, K., Pell, R.G., Chambers, G.N., Tomlinson, P.D., \& Roper, T. (2006). Becoming a Teacher: Student teachers' experiences of initial teacher training in England. Nottingham: Department for Education and Skills (DfES). Retrieved December 22, 2012, from http://www.dfes.gov.uk/research/data/uploadfiles/RR744.pdf

Hunt, B. C. (2009). Teacher Effectiveness: A Review of the International Literature and Its Relevance for Improving Education in Latin America. Working Paper Series No. 43 Washington, DC: PREAL.

Kardia, D. E., \& Wright, M. C. (2004). Instructor Identity: The impact of Gender and Race on faculty experiences with Teaching. CRLT Occasional Papers. University of Michigan. No.19.

King, K., \& Palmer, R. (2006). Skills Development and Poverty Reduction: The State of the Art, Post-Basic Education and Training Working Paper Series No. 9, Centre of African Studies, University of Edinburgh.

Kuh, G. D., Nelson Laird T. F., \& Umbach, P. D. (2004). Aligning faculty and student behavior: Realizing the promise of Greater Expectations. Liberal Education, 90(4), 24-31.

Kumari, J. (2016). Public-private partnerships in education: An analysis with special reference to Indian school education system. International Journal of Educational Development, 47, 47-53. https://doi.org/10.1016/j.ijedudev.2015.11.017

Lacey, C.H., Saleh, A., \& Gorman, R. (1998). Teaching nine to five: A study of the teaching styles of male and female professors. Paper presented at the Annul Women in Education Conference, Lincoln, Nebraska, October 11-12.

Lombardo, E. (2005). Integrating or Setting the Agenda? Gender Mainstreaming in the European Constitution-Making Process. Social Politics, 12(3), 412-432. https://doi.org/10.1093/sp/jxi022

Macharia, S.N., \& Wario L.H. (1994). Teaching Practice in Primary Schools. Macmillan, Lusaka. pp. 17-29.

Markauskaite, L. (2006). Gender issues in preservice teachers' training: ICT literacy and online learning. Australasian Journal of Educational Technology, 22(1) 1-20. https://doi.org/10.14742/ajet.1304

Mazey, S. (2000). Introduction: Integrating gender - intellectual and "real world" mainstreaming. Journal of European Public Policy, 7(3), 333-45. https://doi.org/10.1080/13501763.2000.11500071

National Survey of Student Engagement (2005). Exploring different dimensions of students engagement. Bloomington, IN: Indiana University Centre for Post secondary Research.

Nelson Laird, T. F., Garver, A. K., \& Niskodé, A. S. (2007). Gender gaps: Understanding teaching style differences between men and women. Paper presented at the annual forum of the Association for Institutional Research, Kansas City, MO. 
Ng, P. L., \& Tan, A. K. (2017). Determinants of e-resource usage by open distance learning university students. Malaysian Journal of Library \& Information Science, 22(1), 29-44.

Oduro, G. K.T. (1998), Moving from Teacher Accountability to Teacher Development. Lessons from Teacher Appraisal. Journal of Educational Management (I.E.P.A.), 1(1), 64 -82.

Rubio, M. C. (2009). Effective teachers Professional and personal skills. Retrieved December 12, 2012, from http://www.uclm.es/ab/educacion/ensayos.http://nsse.iub.edu/html/pubs.cfm

Shulman, L. S. (1986). Those who understand: Knowledge growth in teaching. Educational Researcher, 15(2), 4-14. https://doi.org/10.3102/0013189X015002004

Singer, E. (1996). Espoused teaching paradigms of college faculty. Research in Higher Education, 37(6), 659 - 679. https://doi.org/10.1007/BF01792951

Starbuck, G.H. (2003). College teaching styles by gender. Paper presented at the Western Social Science Association Annual Meeting, Las Vegas, NV, April 9-12.

Statham, A. Richardson, I., \& Cook, J. A. (1991). Gender and University teaching: A negotiated difference. Albany: State University of New York Press.

UNESCO (2001). Teacher Education Through Distance Learning. Technology-Curriculum-Cost-Evaluation. International Research Foundation for Open Learning, (IRFOL), Cambridge, UK.

Verloo, M. (2001). Another Velvet Revolution? Gender Mainstreaming and the Politics of Implementation. IWM working Paper No. 5/2001. Institute for Human Sciences, Vienna.

Walby, S. (2001). From community to coalition: the politics of recognition as the handmaiden of the politics of redistribution. Theory, Culture and Society, 18(2-3), 113-135. https://doi.org/10.1177/02632760122051814

Walby, S. (2004). Gender mainstreaming: Productive tensions in theory and practice. Contribution to ESRC Gender Mainstreaming Seminars, 2003-4. University of Leeds.

Woodward, A. (2003). European Gender Mainstreaming: Promises and Pitfalls of Transformative Policy. Review of Policy Research, 20(1), 65-88. https://doi.org/10.1111/1541-1338.00005 